\title{
Model Prediksi Hasil Panen Berdasarkan Pengukuran Non-Destruktif Nilai Klorofil Tanaman Padi
}

\author{
Rice Yield Prediction Model Based on Nondestructive Measurements of Rice Chlorophyll Values Paddy Leaf \\ Fitri Hidayah*, S. Santosa, Renny Eka Putri \\ Program Studi Teknik Pertanian, Teknologi Pertanian, Universitas Andalas, \\ Kampus Limau Manis, Jl. Universitas Andalas, Limau Manis, Kecamatan Pauh, Kota Padang, \\ Sumatera Barat 25163, Indonesia \\ *Email: fitrihidayah222@gmail.com
}

Tanggal submisi: 19 April 2018; Tanggal penerimaan: 26 September 2019

\begin{abstract}
ABSTRAK
Pembuatan model prediksi hasil panen dilakukan untuk memprediksi hasil produksi pada tanaman padi berdasarkan nilai klorofil tanaman padi pada umur yang berbeda. Model dikembangkan berdasarkan data spatial variability nilai klorofil dari hasil pengukuran dengan cara nondestruktif menggunakan klorofil meter CCM-200 plus pada umur 25, 40, 60, dan 70 hari setelah tanam (HST) dan hasil panen tanaman padi. Model prediksi hasil dibuat bertujuan untuk menjelaskan hubungan antara nilai klorofil terhadap hasil panen pada umur yang berbeda yang diperoleh dari 20 titik pengamatan pada sawah Banda Langik, di Desa Sungai Bangek, Lubuk Minturun, Kecamatan Koto Tangah, Kota Padang. Pengumpulan sampel data dilakukan dengan dua cara yaitu, grid sampling point dan crop cutting test (CCT). Pengukuran kandungan klorofil atau jumlah SPAD (soil plant analyses development) pada daun tanaman dilakukan menggunakan klorofil meter CCM-200 plus. Berdasarkan penelitian yang telah dilakukan menunjukkan bahwa nilai klorofil memiliki hubungan dengan hasil produksi tanaman padi. Hal ini dibuktikan melalui nilai korelasi yang dihasilkan, pada umur $25 \mathrm{HST}(r=0,945), 40 \mathrm{HST}(r$ $=0,887), 60 \mathrm{HST}(r=0,835)$ dan $70 \mathrm{HST}(r=0,897)$. Hasil panen pada tanaman padi dapat diprediksi melalui model berikut: $Y=-0,431513+0,045144 X_{1}+0,03645 X_{2}+0,01017 X_{3}+0,020551 X_{4}$ dengan $Y$ adalah hasil produksi panen $\left(\mathrm{kg} / \mathrm{m}^{2}\right)$ dan $X$ adalah nilai klorofil pada umur yang berbeda $\left(X_{1}=25 \mathrm{HST}\right),\left(X_{2}=40 \mathrm{HST}\right),\left(X_{3}\right.$ $=60 \mathrm{HST})$ dan $\left(\mathrm{X}_{4}=70 \mathrm{HST}\right)$. Model tersebut dihasilkan melalui proses uji regresi linear berganda berdasarkan data nilai klorofil dan hasil produktivitas tanaman padi selama satu kali musim.
\end{abstract}

Kata kunci: Crop cutting test (CCT); grid sampilng; nilai klorofil (SPAD); spatial variability

\begin{abstract}
Developing yield prediction model was done to predict the production of rice crops based on chlorophyll value at different age levels. A model was developed by using spatial variability data of chlorophyll value. It was measured with a non-destructive method by using chlorophyll meter CCM-200 plus at different age levels in terms of days after planting 25, 40,60 and 70 (DAP), and yield of rice. The objective of developing yield prediction model was to describe correlation between chlorophyll value and yield at different ages that had been obtained from 20 observation plots at the rice field. The study area was in Banda Langik, Sungai Bangek village, Lubuk Minturun of Koto Tangah sub district in Padang. Data were collected in two systems; grid sampling point and crop cutting test (CCT). Measuring of chlorophyll contained in leaf or number of SPAD (soil plant analysis development) was done by using chlorophyll meter CCM-200 plus. The research showed that chlorophyll value in rice crop correlated with yield. It was proved by correlation index obtained in each stage of age; 25 DAP ( $r=$ $0.945), 40 \operatorname{DAP}(r=0.887), 60$ DAP $(r=0.835)$ and 70 DAP $(r=0.897)$. Rice yield could be predicted through
\end{abstract}


following model: $Y=-0.431513+0.045144 X 1+0.03645 X 2+0.01017 X 3+0.020551 X 4$, where $Y$ was the rice yield $(\mathrm{kg} / \mathrm{m} 2)$ and $X$ was chlorophyll value at different age levels $(X 1=25$ DAP), $(X 2=40 \mathrm{DAP}),(X 3=60 \mathrm{DAP})$ and $(X 4=70 \mathrm{DAP})$. The model was produced through a multiple linear regression test based on chlorophyll value data and rice productivity during 1 period of harvest session.

Keywords: Chlorophyll value (SPAD); crop cutting test (CCT); grid sampilng; spatial variability

\section{PENDAHULUAN}

Tanaman padi (Oryza sativa L.) adalah tanaman penghasil beras yang merupakan komoditas pangan yang dijadikan sebagai makanan pokok bagi bangsa Indonesia. Menurut Suryana dan Mardianto (2001) beras mempunyai peran yang strategis dalam memantapkan ketahanan pangan. Ketersediaan pangan yang tercukupi merupakan salah satu kunci utama dalam menentukan kondisi ketahanan pangan disuatu negara. Ketika beras tercukupi maka kebutuhan pangan pokok masyrakat terpenuhi.

Pada saat sekarang ini tanaman padi di Indonesia mengalami penurunan produktivitas (Pingali dkk., 1997). Untuk mencegah terjadinya penurunan produktivitas yang dialami sekarang dapat dilakukan dengan berbagai cara salah satunya, dilakukan pengembangan teknologi yang sudah ada sebelumnya untuk membantu meningkatkan produktivitas tanaman padi seperti pengembangan model yang dapat memprediksi hasil panen tanaman padi berdasarkan spatial variability dari pengukuran nondestruktif nilai klorofil tanaman.

Putri dkk. (2016) menjelaskan bahwa nilai SPAD memiliki hubungan yang erat dengan kesehatan tanaman yang dapat ditentukan berdasarkan hasil produksi panen padi yang didapat melalui metode ubinan crop cutting test. Tanaman yang subur dan cukup nutrisi akan terlihat hijau pada daunnya dan menandakan kandungan Nitrogen $(\mathrm{N})$ yang tercukupi dan juga sebaliknya, jika kandungan nutrisi tercukupi dengan baik maka produktivitas tanaman juga akan semakin tinggi (Cen dkk., 2006). Dengan mengetahui nilai SPAD yang terkandung pada tanaman juga akan memberikan informasi tentang kandungan $\mathrm{N}$ yang terkandung pada daun (Gholizadeh dkk., 2009).

Pengukuran nilai klorofil tanaman padi dengan klorofil meter (SPAD meter) telah banyak dilakukan dan digunakan untuk menganalisis kandungan klorofil pada daun dan status $\mathrm{N}$ dari tanaman akan tetapi belum berkelanjutan.Untuk itu pada penelitian ini dilakukan pembuatan model yang dapat memprediksi hasil panen berdasarkan pembacaan nilai klorofil pada daun tanaman dan hasil produksi panen (Putri dkk., 2016).

Untuk meningkatkan produktivitas padi petani sering kali menghadapi kendala seperti, kesulitan dalam menentukan kebutuhan nutrisi tanaman padi pada saat yang tepat dan kesulitan dalam memantau perkembangan tanaman secara cepat di suatu area lahan yang diamati oleh sebab itu diperlukan model matematis yang dapat memprediksi hasil berdasarkan nilai klorofil dan hasil panen pada tanaman padi, yang dapat mencakup area yang luas, handal dengan waktu yang cepat serta hasil yang cukup akurat (Barrett dan Curtis, 1982).

Metode pengukuran tingkat kehijauan daun yang umum dilakukan saat ini adalah dengan pengukuran Bagan Warna Daun (BWD), akan tetapi metode ini belum efektif dan akurat dalam mengukur kandungan klorofil yang terkandung pada daun tanaman padi karena BWD tidak dapat dapat menunjukan perbedaan warna hijau daun yang terlalu kecil sebagaimana pada khlorofil meter (SPAD). Namun, BWD bisa dibandingkan dengan SPAD untuk menentukan ketepatan relatifnya dalam menentukan status N tanaman padi (Gani, 2006) dan teknologi baru yang bersifat nondestruktif sudah dikembangkan menggunakan klorofil meter (SPAD meter) yaitu sebuah alat sederhana dapat menentukan jumlah klorofil dalam daun tanaman disebut SPAD52 (KONICA MINOLTA 1989), namun pembacaan ini belum bersifat berkelanjutan karena masih bersifat objektif maka perlu adanya proses kegiatan lanjutan agar memberikan informasi akurat dan berkelanjutan dalam memprediksi hasil maka perlu adanya sebuah pengembangan metode pengukuran untuk memprediksi hasil panen atau hasil produktivitas tanaman padi pada suatu area lahan dengan proses yang mudah dalam pengumpulan dan pengambilan data dilapangan.

Pengembangan metode untuk memprediksi hasil produksi panen di Indonesia berdasarkan kesuburan tanaman belum banyak dilakukan dan untuk mengamati perkembangan tanaman padi tidak dapat berlangsung cepat, tepat, dan mencakup areal lahan yang luas jika pengukuran dilakukan hanya menggunakan klorofil meter. Oleh sebab itu tujuan dari penelitian ini adalah mengembangkan model matematis untuk memprediksi hasil panen yang diprediksi melalui nilai klorofil pada daun tanaman padi, dan mengevaluasi hubungan antara jumlah klorofil dan hasil produksi pada tanaman padi yang dilihat berdasarkan keragaman (variability) dari hasil panen (yield) pada petakan sawah yang diperoleh melalui metode crop cutting test (CCT). 


\section{BAHAN DAN METODE}

\section{Alat dan Bahan}

Alat yang digunakan pada penelitian ini terdiri dari klorofil meter (CCM-200 plus Opti-Science) USA, alat tulis (pensil dan buku), alat ukur (meteran dan timbangan), seperangkat peralatan pengolah data yang terdiri dari laptop dan USB, Software untuk pengolahan data dan analisis data yang terdiri dari Microsoft Word, Excel, Statistical Product and Service Solutions (SPSS), dan SAS.

Pada penelitian ini tanaman padi dengan luasan 0,5 ha dijadikan sebagai sampel penelitian. Untuk sampel data diambil 5 rumpun tanaman padi di tiaptiap plot pada masing-masing titik pengamatan yang sudah ditentukan. Bibit padi yang digunakan pada penelitian adalah padi IR 42, lahan dibagi ke dalam 20 titik pengamatan dalam bentuk petak/ubinan ukuran dari masing-masing petakan lahan yaitu $25 \times 10 \mathrm{~m}$.

\section{Deskripsi Tempat Penelitian}

Penelitian ini dilaksanakan di daerah persawahan Desa Sungai Bangek, Lubuk Minturun, Kecamatan Koto Tangah, Kota Padang. Lahan yang dipakai adalah lahan pertanian dari kelompok tani Banda Langik, nama dari kelompok tani ini berasal dari nama daerah persawahan tersebut. Kondisi lahan penelitian memiliki jenis tanah lempung pasir berliat, berdasarkan pengukuran segitiga tekstur jenis tanah merupakan sampel tanah $\mathrm{A}$, serta memiliki irigasi yang baik, sehingga baik untuk tempat bercocok tanam padi. Menurut letak geografis pada peta daerah persawahan banda langik terletak pada titik koordinat ( $\left.00^{\circ} 49^{\prime} 52.2^{\prime \prime} \mathrm{LS}-100^{\circ} 21^{\prime} 17.8^{\prime \prime} \mathrm{BT}\right)$.

\section{Metode Pengumpulan Data}

Pengumpulan sampel data pada penelitian ini dilakukan dengan dua cara yaitu: Grid sampling dan crop cutting test(CCT) (Putri, 2016). Grid sampling point yaitu proses pengambilan data yang dilakukan untuk menggambarkan kondisi lahan berdasarkan tingkat kesuburan dari tanaman dengan cara membagibagi sampel tanaman ke dalam beberapa bagian. Caranya yaitu membaqi lahan sawah meniadi beberapa

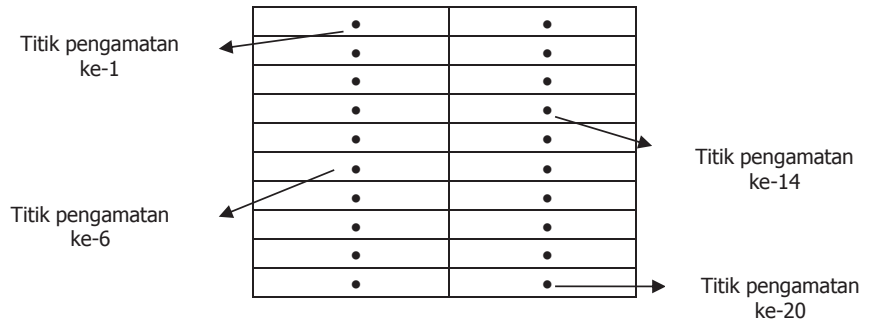

Gambar 1. Grid sampling point kelompok kemudian dibagi dalam bentuk petakanpetakan. Selanjutnya dilakukan proses pengumpulan data langsung dilapangan untuk mendapatkan informasi langsung dari tanaman, yang dijadikan sebagai sampel data untuk diolah. Untuk lahan seluas 0,5 ha dibagi menjadi 20 grid kemudian menentukan titik pengamatan dari tiap masing-masing petakan. Untuk proses grid sampling dapat dilihat pada Gambar 1.

Gambar 1 merupakan metode pembagian lahan ke dalam beberapa petakan yang dijadikan sebagai titik pengamatan. Pemberian tanda titik pengamatan pada lahan area penelitian dilakukan berurutan untuk mempermudah dalam proses pengambilan, pengamatan, dan pengelolaan data.

Metode Ubinan atau crop cutting test (CCT) adalah suatu metode pengambilan dan pengumpulan sampel data tanaman yang dilakukan langsung di lapangan yang dipakai pada saat panen untuk setiap petak lahan yang dijadikan sebagai sampel penelitian. Adapun langkah untuk melakukan CCT yaitu: (1) menentukan dan memberikan tanda pada petakan sawah yang dijadikan percobaan dan menentukan ukuran-ukuran pada petakan sawah yang sudah dipilih, (2) pemanenan dengan cara CCT, (3) perontokan hasil panen dari tanaman yang dipanen dari area CCT, (4) menampi dan menimbang biji padi atau gabah basah yang diperoleh dari petakan sawah CCT (Putri dkk., 2016).

\section{Pengambilan Data Kandungan Klorofil pada Daun Tanaman Padi Menggunakan Klorofil Meter CCM-200 plus}

Pengamatan jumlah kandungan klorofil daun dilakukan sesuai dengan titik-titik pengamatan yang telah ditentukan pada lahan. Kemudian pengambilan data nilai klorofil pada tanaman dilakukan dan dikumpulkan sesuai dengan titik pengamatan yang telah dipilih untuk dijadikan sampel data. Proses pembacaan status klorofil pada daun dilakukan pada empat tahap tanaman tumbuh yaitu saat padi berumur 25, 40, 60, dan 70 hari setelah tanam (HST). Pengambilan data pertama dilakukan pada saat tanaman padi berumur 25 HST, pengambilan data pada hari ke-25 HST dikarenakan masih merupakan fase vegetatif pada tanaman padi, pada fase ini masih merupakan fase perkembangan tanaman yang akan menjadi penentu produktivitas padi, kemudian penentuan waktu pengambilan data pada hari ke-40, ke-60, dan ke-70 karena masih merupakan fase generatif (reproduktif) pada tanaman padi (IRRI, 2002).

Tanaman yang dijadikan sebagai sampel data diperiksa disetiap tahap tumbuhnya pada tiap-tiap petakan sawah yang masing-masing terdiri atas 20 
titik poin. Pada penelitian ini 5 rumpun tanaman padi 5 batang, 5 daun, dan 3 pembacaan nilai klorofil tanaman dengan cara SPAD pada setiap tanaman diambil menggunakan klorofil meter CCM-200 plus. Adapun cara pengumpulan dan pengambilan data kandungan klorofil pada daun menggunakan korofil meter CCM-200 plus dilakukan secara acak. Kemudian nilai klorofil yang diperoleh dari masing-masing pembacaan pada setiap sampel tanaman yang digunakan pada masing-masing titik kemudian diambil nilai rata-ratanya. Nilai rata-rata dari pembacaan klorofil meter CCM-200 plus digunakan sebagai sampel data yang akan diolah. Pengukuran nilai klorofil yang terkandung pada daun akan dikumpulkan antara jam 10:00-15:00 siang, kondisi cuaca cerah dengan suhu rata-rata $32{ }^{\circ} \mathrm{C}$ dan kelembaban antara 40-70\%, hal ini disebabkan oleh kondisi lingkungan berubah setiap harinya pada saat pengambilan data. Pada saat melakukan pengukuran sinar matahari harus relatif cerah untuk menghindari gangguan (noise) dalam data. Pengukuran diambil dibagian paling atas dari daun yaitu daun paling atas sebelum daun bendera keluar dan daun bendera setelah keluar, karena ini adalah daerah yang biasa dipakai dalam praktek pengambilan data nilai tingkat kehijauan daun (Putri dkk., 2016). Sampling point dari bagian daun yang dijadikan sebagai pengukuran yaitu terletak pada ujung, tengah dan pangkal daun padi. Adapun teknik pengukuran klorofil yang dilakukan selama di lapangan yaitu pengukuran dilakukan pada masing-masing titik sampel yang sudah dipilih, pengambilan data sampel sesuai dengan titik tengah pada masing-masing petakan, dan pemilihan tanaman secara acak dan melakukan pembacaan pengukuran sebanyak tiga kali pada masing-masing daun yang dipilih, agar data yang diambil akurat.

Untuk proses pengambilan data nilai klorofil tanaman padi dilapangan menggunakan CCM-200 Plus dapat dilihat pada Gambar 2.

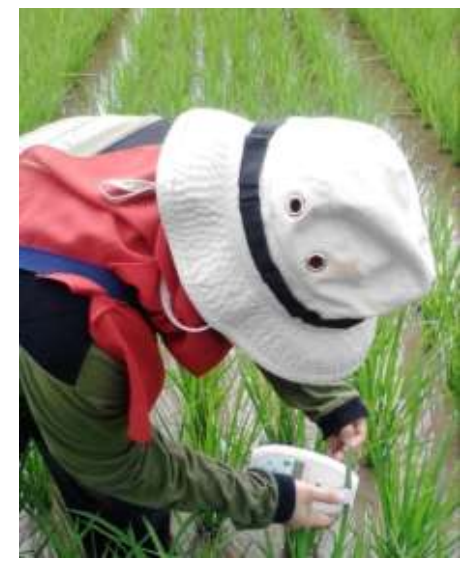

Gambar 2. Pengambilan data nilai klorofil menggunakan CCM200 Plus

\section{Model Prediksi Hasil Produksi Tanaman Padi Berdasarkan Peta Hasil Produksi}

Model Prediksi dibuat menggunakan regresi linear berganda, untuk menjelaskan hubungan respon $Y$ ( hasil produksi (Yield) sesaat), untuk variabel, $\mathrm{X}$ (nilai klorofil pada 25 HST, 40 HST, 60 HST, dan 70 HST), dan $\mathrm{Y}$ adalah fungsi dari $\mathrm{X}_{1}, \mathrm{X}_{2}, \mathrm{X}_{3}$, dan $\mathrm{X}_{4}$ (Santosa, 2012). Model prediksi hasil padi dihitung sesuai Persamaan 1.

$Y=a_{0}+a_{1} X_{1}+a_{2} X_{2}+a_{3} X_{3}+a_{4} X_{4}$

dimana:

$\mathrm{Y}$ : hasil produksi panen (ton/ha)

ao: nilai intercept

$\mathrm{X}_{1}$ : nilai klorofil pada $25 \mathrm{HST}$

$\mathrm{X}_{2}$ : nilai klorofil pada $40 \mathrm{HST}$

$\mathrm{X}_{3}$ : nilai klorofil pada $60 \mathrm{HST}$

$\mathrm{X}_{4}$ : nilai klorofil pada $70 \mathrm{HST}$

$a_{1^{\prime} \cdot 2^{*} 3^{*} 4}$ : koefisien $X_{1}, X_{2}, X_{3^{\prime}}$ dan $X_{4}$

dengan $a_{0}, a_{1}, a_{2}, a_{3}$, dan $a_{4}$ adalah koefisien yang diperoleh dari hasil regresi.

Penyelesaian dari persamaan tersebut berupa sekumpulan empat persamaan simultan dengan empat nilai yang tidak diketahui yaitu $\mathrm{a}_{0}, \mathrm{a}_{1} \mathrm{a}_{2} \mathrm{a}_{3}$ dan $\mathrm{a}_{4}$ disajikan dalam Persamaan 2 sampai dengan 6 (Santosa, 2012).

$n \cdot a_{0}+\sum X_{1} \cdot a_{1}+\sum X_{2 i} \cdot a_{2}+\sum X_{3 i} \cdot a_{3}+\sum X_{4 i} \cdot a_{4}=\sum Y_{i}$

$\sum X_{1} \cdot a_{0}+\sum X_{l_{i}}^{2} \cdot a_{1}+\sum X_{1 i} X_{2 i} \cdot a_{2+}, \sum X_{1 i} X_{3 i} \cdot a_{3+}, \sum X_{1 i} X_{4 i} \cdot a_{4}=\sum X_{l_{i}} Y_{i}$

$\sum X_{2 i} a_{0}+\sum X_{2 i} X_{i} \cdot a_{1}+\sum X_{2 i}^{2} \cdot a_{2+} \sum X_{2 i} X_{3 i} \cdot a_{3+} \sum X_{2 i} X_{4 i} \cdot a_{4}=\sum X_{2 i} Y_{i}$

$\sum X_{3 i} a_{0}+\sum X_{3 i} X_{1 i} \cdot a_{1}+\sum X_{3 i} X_{2 i} \cdot a_{2}+\sum X_{3 i}^{2} \cdot a_{3}+\sum X_{3 i} X_{4 i} \cdot a_{4}=\sum X_{3 i} Y_{1}$

$\sum X_{4 i} \cdot a_{0}+\sum X_{4 i} X_{1} \cdot a_{1}+\sum X_{4 i} X_{2 i} \cdot a_{2}+\sum X_{4 i} X_{3 i} \cdot a_{3+} \sum X_{4}^{2} \cdot a_{4}=\sum X_{4 i} Y$

Dengan $n$ adalah banyaknya pasangan data $\left(X_{1}, X_{2}, X_{3}\right.$ $\left.\mathrm{X}_{4}, \mathrm{Y}\right)$.

\section{Uji Korelasi Data}

Tujuan uji korelasi pada data dilakukan untuk melihat seberapa besar keterkaitan dan kuat hubungan antara kedua data, yaitu data nilai klorofil yang diperoleh dan hasil produksi tanaman padi pada suatu areal lahan. Analisis regresi pada dasarnya adalah studi mengenai ketergantungan variabel dependen (terikat) dengan satu atau lebih variabel independen (variabel penjelas atau variabel bebas), dengan tujuan untuk mengestimasi dan/atau memprediksi rata-rata populasi atau nilai rata-rata variabel dependen berdasarkan nilai variabel independen yang diketahui (Gujarati, 2003). Analisis korelasi bertujuan untuk mengukur kekuatan asosiasi (hubungan) linear antara dua variabel. Untuk uji korelasi data pada penelitian ini akan diuji menggunakan program SPSS. Kuat hubungan antara data akan dinyatakan dalam bentuk angka antara $0-1$, 
Tabel 1. Pedoman umum penentuan korelasi

\begin{tabular}{cc}
\hline$r$ & Kriteria hubungan \\
\hline 0 & Tidak ada korelasi \\
$0-0,5$ & Korelasi lemah \\
$0,5-0,8$ & Korelasi sedang \\
$0,8-1$ & Korelasi kuat/erat \\
1 & Korelasi sempurna \\
\hline
\end{tabular}

jika angka yang dihasilkan oleh korelasi data adalah 0 maka menunjukkan tidak adanya hubungan antara data dan jika menunjukkan angka 1 maka menunjukan hubungan yang sempurna antara data. Jika semakin kecil koefisien korelasi, maka akan semakin besar kesalahan untuk membuat prediksi. Sebagai acuan untuk melihat kuat hubungan antara data tingkat hijau daun dan hasil produksi panen dapat dilihat pada Tabel 1.

\section{HASIL DAN PEMBAHASAN}

\section{Hasil dan Nilai Klorofil yang Didapatkan di Lapangan Berdasarkan Variasi Umur Tanaman Padi pada umur 25, 40, 60, dan 70 HST}

Pengukuran nilai klorofil pada tanaman padi dilakukan menggunakan CCM-200 pluspada umur 25, 40, 60 , dan 70 hari setelah tanam (HST). Pada penelitian ini pengukuran nilai klorofil dilakukan untuk mengumpulkan nilai klorofil dari tanaman padi yang bertujuan untuk melihat pengaruh nilai klorofil pada umur yang berbeda terhadap hasil produksi yang dihasilkan pada lahan. Pembacaan nilai klorofil pada setiap bagian permukaan daun berbeda-beda, maka nilai klorofil dikumpulkan dari rata-rata pembacaan yang dilakukan pada satu daun. Berdasarkan hasil pengamatan nilai klorofil yang telah dilakukan selama satu kali musim tanam beserta dengan hasil produksinya, dapat dilihat bahwa nilai klorofil pada tanaman padi mengalami perubahan disetiap tahap pertumbuhan tanaman padi yaitu pada fase vegetatif dan generatif (reproduktif). Pada masa awal yaitu masa vegetatif, tanaman padi menunjukkan bahwa nilai klorofil masih sangat rendah pada umur 25 HST yaitu sekitar $3,35-10,21$, nilai klorofil masih sangat rendah kondisi tanaman padi dalam kondisi tumbuh, daun bertambah banyak dan menghasilkan anakan. Pada umur 40 HST tanaman mulai tumbuh berkembang dan bertambah tinggi dengan nilai klorofil 15,84 - 19,86. Pada umur 60 HST padi sudah mulai bunting, daun bendera sudah mulai keluar dan terbuka sempurna, nilai klorofil yaitu 14,25 - 20,43, sedangkan pada umur 70 HST malai padi sudah mulai keluar dengan nilai klorofil 17,03-25,58.
Berdasarkan hasil pengukuran yang didapatkan dari tanaman padi menunjukkan bahwa nilai klorofil paling tinggi yaitu pada umur 40 HST dan umur 70 HST. Pada umur 40 HST daun tanaman padi memiliki nilai klorofil lebih tinggi daripada umur 25 HST dan 60 HST. Pada umur 60 HST nilai klorofil pada tanaman padi mengalami penurunan dapat dilihat dari nilai rata-rata klorofil tanaman padi yang diproleh. Kemudian pada umur 70 HST nilai klorofil pada tanaman padi semakin tinggi dapat dilihat dari rata-rata nilai klorofil pada daun tanaman. Untuk melihat bagaimana lebih jelasnya penurunan dan peningkatan nilai klorofil pada masingmasing pertumbuhan berdasarkan umur tanaman padi pada dapat dilihat pada Gambar 3.

Gambar 3 adalah grafik yang menyajikan peningkatan dan penurunan nilai klorofil tanaman padi berdasarkan nilai rata-rata dari pengukuran nilai klorofil pada tanaman padi yang dilakukan selama satu kali musim tanam. Berdasarkan Gambar 3 pada grafik dapat dilihat bahwa pada umur 25, 40,60, dan 70 HST nilai klorofil pada tanaman padi berbeda ditiap tahap pertumbuhannya. Maksum (1998) menunjukkan bahwa jika grafik indek vegetasi selama pertumbuhan tanaman padi mulai awal tanam sampai siap dipanen berbentuk parabolic dan pada hasil penelitian pada Gambar 2 menunjukkan bahwa data berbeda dan mengalami perubahan di setiap pertumbuhannya.

Dari pengamatan yang telah dilakukan nilai klorofil pada tanaman mengalami penurunan dan peningkatan karena dipengaruhi oleh faktor kecukupan nutrisi pada tanaman dapat dilihat pada umur 40 dan 70 HST nilai klorofil lebih tinggi setelah dilakukannya pemupukan pada tanaman. Pada umur 70 HST menunjukkan memiliki tingkat nilai klorofil paling tinggi dibandingkan dengan umur 40 dan 60 HST, pemupukan ke-2 pada umur 70 HST memiliki pengaruh besar terhadap kecukupan nutrisi $\mathrm{N}$ pada tanaman padi. Jadwal pemupukan untuk lahan pemupukan pertama dilakukan pada umur 21 HST dan pemupukan kedua pada umur 63 HST. Pemupukan ini dilakukan untuk mencukupi kebutuhan nutrisi pada tanaman padi dan menunjang pertumbuhan dari tanaman padi. Furuya (2007)

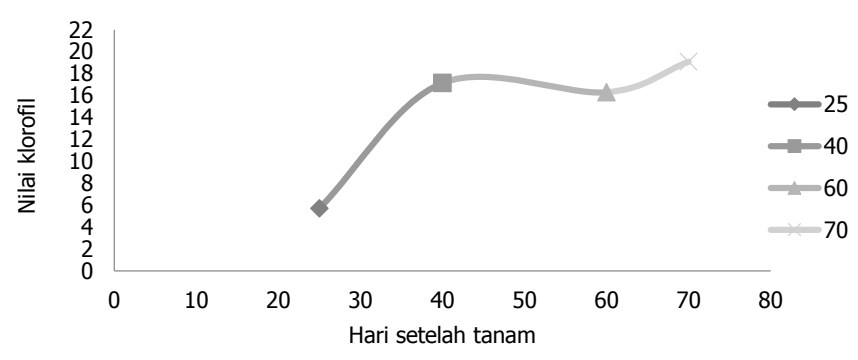

Gambar 3. Peningkatan nilai klorofil tanaman padi umur 25, 40, 60 , dan 70 HST 
melaporkan bahwa selama tahun 1980-an warna daun menjadi lebih diperhatikan karena warna daun paling baik menunjukkan status nutrisi tanaman. Tanaman yang subur dan cukup nutrisi akan terlihat hijau pada daunnya dan menandakan kandungan Nitrogen $(\mathrm{N})$ yang tercukupi dan juga sebaliknya, jika kandungan nutrisi tercukupi dengan baik maka produktivitas tanaman juga akan semakin tinggi (Cen dkk., 2006). Sejak tahun 1980-an warna daun menjadi lebih diperhatikan karena dapat dijadikan sebagai alat terbaik untuk menunjukkan kesehatan dan kecukupan nutrisi dari daun tanaman padi. Semenjak daun pada tanaman dapat dijadikan sebagai alat untuk menentukan kebutuhan nutrisi tanaman pengukuranwarna daun semakin maju dan penelitian tentang daun semakin sering dilakukan karena dapat mempermudah pengukuran dilapangan. Untuk mempermudah proses pengukuran warna hijau daun dilapangan dapat dilakukan dengan menggunakan dua metode yaitu pengukuran dengan menggunakan alat sederhana dan pengukuran menggunakan peralatan mesin (Furuya, 1987)

Menurut penelitian Putri dkk. (2016) menunjukkan bahwa nilai klorofil yang diperoleh dari pengukuran nilai SPAD pada tanaman memiliki hubungan erat dengan kesehatan tanaman yang ditentukan berdasarkan hasil produksi panen pada tanaman padi yang didapat melalui metode ubinan crop cutting test (CCT).

\section{Uji ANOVA (Analysis of Variance) Berdasarkan Variability Nilai Klorofil Tanaman Padi (SPAD)}

Uji ANOVA data pada penelitian dilakukan, bertujuan untuk mengetahui pengaruh faktor umur terhadap nilai klorofil berdasarkan perbedaan umur, yaitu umur 25, 40, 60, dan 70 HST dengan melihat nilai signifikan dari masing-masing sampel data. Perbedaan yang sangat signifikan antara nilai klorofil dan tahap pertumbuhan yang berbeda dapat dikaitkan dengan tingkat pertumbuhan padi yang berbeda. Menurut Turner (1991) mencatat adanya hubungan linier yang kuat antara nilai klorofil dan konsentrasi nitrogen total daun yang bervariasi dengan tingkat pertumbuhan tanaman. Taraf untuk kepercayaan pada hasil uji ANOVA ini yaitu ketika nilai signifikan lebih kecil dari 0,05. Untuk mengetahui tingkatan dari nilai klorofil pada umur yang berbeda dapat dilihat pada Tabel 2 .
Berdasarkan Tabel 2 melalui uji ANOVA yang telah dilakukan pada umur 25, 40, 60, dan 70 HST bahwa faktor umur berpengaruh terhadap nilai rata-rata klorofil pada tanaman padi. Nilai klorofil mengalami peningkatan yang berbeda disetiap fase pertumbuhan tanaman padi sesuai dengan umur. Melalui uji anova yang telah dilakukan menghasilkan nilai signifikan yaitu 0,0001 . Hal ini membuktikan bahwa faktor umur sangat berpengaruh terhadap nilai klorofil tanaman padi. Berdasarkan dari nilai tersebut juga, menunjukkan bahwa pada umur yang berbeda yaitu pada umur 25 , 40, 60, dan 70 HST memiliki nilai rata-rata klorofil yang berbeda nyata antara 20 titik pengamatan. Selain itu, juga dapat dilihat bahwa nilai klorofil pada lahan beragam pada masing-masing titik pengamatan.

Pada uji anova yang dilakukan terhadap data hasil pengamatan hanya memberikan indikasi tentang ada tidaknya beda antara rata-rata dari nilai klorofil, sehingga bila uji dinyatakan berbeda secara signifikan, berarti secara keseluruhan ada perbedaan, jika ada perbedaan nyata akan diuji lanjut (Sastrosupadi, 2000; Hanafiah, 2004).

\section{Hubungan Nilai Klorofil terhadap Hasil Produksi pada Tanaman Padi}

Berdasarkan penelitian dan pengamatan yang telah dilakukan di lapangan diperoleh hasil bahwa nilai klorofil pada tanaman berpengaruh terhadap hasil produksi tanaman padi. Menurut Murthy dkk. (1995), Theruvengadachari dkk. (1997) dan Lapan, (2000), terdapat hubungan antara tingkat kehijauan tanaman (greenness) dengan produktivitas tanaman padi sawah (didapat dari ubinan/crop cutting experiment). Nilai klorofil tanaman padi pada masing-masing titik pengamatan pada umur yang berbeda dapat dilihat pada Tabel 3.

Pada Tabel 3 dapat dilihat data nilai klorofil pada masing-masing titik pengamatan yang diukur menggunakan CCM-200 Plus. Untuk mengetahui bahwa nilai klorofil mempunyai hubungan dan pengaruh terhadap hasil produksi dilakukan uji korelasi data. Melalui uji korelasi data yang dilakukan akan dilihat keterkaitan, hubungan dan pengaruh nilai klorofil dengan hasill produksi. Data yang akan diuji yaitu data nilai klorofil dari hasil pengukuran yang didapatkan dari

Tabel 2. Uji Anova nilai klorofil pada umur 20, 40, 60, dan 70 HST

\begin{tabular}{llllll}
\hline Sumber keragaman & Derajat bebas & Kuadrat total & Kuadrat tengah & $\mathrm{F}_{\text {hitung }}$ & Signifikan \\
\hline Umur tanaman & 3 & 54374,22690 & 18124,74230 & 4907,22 & 0,0001 \\
Titik pengamatan & 19 & 6705,55918 & 352,92417 & 95,55 & 0,0001 \\
\hline
\end{tabular}


Tabel 3. Data nilai klorofil yang diambil menggunakan klorofil meter CCM-200 plus

\begin{tabular}{cccccc}
\hline $\begin{array}{c}\text { Titik } \\
\text { Pengamatan }\end{array}$ & 25 HST $\left(\mathrm{X}_{1}\right)$ & 40 HST $\left(\mathrm{X}_{2}\right)$ & $60 \mathrm{HST}\left(\mathrm{X}_{3}\right)$ & 70 HST $\left(\mathrm{X}_{4}\right)$ & $\begin{array}{c}\text { Hasil produksi }\left(\mathrm{kg} / \mathrm{m}^{2}\right) \\
(\mathrm{Y})\end{array}$ \\
\hline 1 & 6,000 & 16,612 & 17,192 & 19,656 & 1,05 \\
2 & 5,248 & 16,424 & 14,712 & 19,552 & 0,92 \\
3 & 3,472 & 15,932 & 14,428 & 17,132 & 0,8 \\
4 & 3,604 & 15,992 & 14,560 & 17,248 & 0,87 \\
5 & 5,304 & 16,480 & 17,164 & 19,600 & 0,95 \\
6 & 6,160 & 16,608 & 18,256 & 21,692 & 1,12 \\
7 & 5,084 & 16,260 & 14,632 & 17,560 & 0,9 \\
8 & 6,192 & 19,564 & 18,588 & 19,392 & 1,22 \\
9 & 9,080 & 20,636 & 16,108 & 22,068 & 1,4 \\
10 & 10,216 & 19,864 & 20,431 & 25,584 & 1,5 \\
11 & 10,076 & 19,680 & 20,348 & 21,908 & 1,28 \\
12 & 5,036 & 16,000 & 14,564 & 17,324 & 0,88 \\
13 & 3,428 & 15,864 & 14,332 & 17,048 & 0,78 \\
14 & 3,352 & 15,840 & 14,252 & 17,032 & 0,68 \\
15 & 5,040 & 16,012 & 14,600 & 17,412 & 0,89 \\
16 & 3,512 & 15,932 & 14,552 & 17,168 & 0,82 \\
17 & 6,184 & 16,880 & 17,216 & 17,488 & 1,07 \\
18 & 5,148 & 16,336 & 14,708 & 17,628 & 0,91 \\
19 & 5,932 & 16,548 & 17,188 & 19,620 & 1,05 \\
20 & 6,052 & 19,488 & 18,212 & 19,684 & 1,08 \\
Rata-rata & 5,706 & 17,148 & 16,302 & 19,090 & 1,0085 \\
Maksimum & 10,216 & 19,864 & 20,431 & 25,584 & 0,68 \\
Minimum & 3,352 & 15,840 & 14,252 & 17,032 & \\
\hline & & & & & \\
\hline
\end{tabular}

lapangan pada umur yang berbeda yaitu pada saat umur tanaman 25, 40,60, dan 70 HST dan hasil produksi dari tanaman padi pada masing-masing titik pengamatan. Untuk melihat pengaruh nilai klorofil terhadap hasil produksi pada umur 25, 40, 60, dan 70 HST dapat dilihat pada Tabel 4.

Pada Tabel 4 dapat dilihat hubungan dan pengaruh nilai klorofil terhadap hasil produksi tanaman padi

Tabel 4. Korelasi nilai klorofil tanaman padi dengan hasil produksi pada umur 25, 40, 60, dan 70 HST

\begin{tabular}{lccccc}
\hline & $\begin{array}{c}\text { Hasil produksi } \\
\left(\mathrm{kg} / \mathrm{m}^{2}\right)(\mathrm{Y})\end{array}$ & $\begin{array}{c}25 \mathrm{HST} \\
\left(\mathrm{X}_{1}\right)\end{array}$ & $\begin{array}{c}40 \text { HST } \\
\left(\mathrm{X}_{2}\right)\end{array}$ & $\begin{array}{c}60 \mathrm{HST} \\
\left(\mathrm{X}_{3}\right)\end{array}$ & $\begin{array}{c}70 \mathrm{HST} \\
\left(\mathrm{X}_{4}\right)\end{array}$ \\
\hline Hasil produksi $\left(\mathrm{kg} / \mathrm{m}^{2}\right)(\mathrm{Y})$ & 1.000 & & & & \\
\hline 25 HST $\left(\mathrm{X}_{1}\right)$ &, 945 & 1,000 & & & \\
\hline 40 HST $\left(\mathrm{X}_{2}\right)$ &, 887 &, 843 & 1,000 & & \\
\hline 60 HST $\left(\mathrm{X}_{3}\right)$ &, 835 &, 813 &, 738 & 1,000 & \\
\hline 70 HST $\left(\mathrm{X}_{4}\right)$ &, 897 &, 885 &, 753 &, 815 & 1,000 \\
\hline
\end{tabular}

Keterangan: Hari setelah tanam (HST) 
berdasarkan umur yang berbeda yaitu pada umur 25 , 40, 60, dan 70 HST. Tabel 4 menunjukkan bahwa nilai klorofil memiliki hubungan dan pengaruh terhadap hasil produksi ditiap masing-masing tahap pertumbuhan yang berbeda dapat dilihat dari nilai korelasi yang dihasilkan pada masing-masing umur yaitu umur 25, 40, 60, dan 70 HST. Berdasarkan tabel keputusan yang telah ditentukan pada Tabel 1 korelasi bahwa, jika nilai $r$ lebih dari 0.6 menandakan bahwa nilai klorofil memiliki hubungan dengan hasil produksi.

Nilai korelasi yang dihasilkan pada umur 25 HST yaitu $r=0,945$, berdasarkan nilai korelasi pada umur 25 HST menunjukkan bahwa nilai klorofil memiliki hubungan yang kuat terhadap hasil produksi padi. Pada umur 25 HST nilai klorofil memiliki pengaruh terhadap hasil produksi pada fase vegetatif karena pada fase ini nilai klorofil berpengaruh terhadap proses pertumbuhan, perkembangan dan pertambahan daun pada anakan tanaman padi.

Pada umur 40 HST nilai klorofil mengalami peningkatan, nilai korelasi antara nilai klorofil dengan hasil produksi yaitu $r=0,887$, berdasarkan nilai korelasi ini menunjukkan nilai klorofil memiliki hubungan yang kuat dengan hasil produksi. Semakin tinggi jumlah nilai klorofil pada tanaman, maka semakin berpengaruh terhadap hasil produksi. Pada umur 40 HST nilai klorofil pada tanaman padi mengalami peningkatan ketika dilakukan pemupukan. Peningkatan nilai klorofil pada tanamanan padi umur 40 HST ini menunjukkan bahwa, semakin tercukupinya nilai $\mathrm{N}$ sehingga meningkatkan nilai klorofil pada tanaman dan hal ini juga menandakan pemupukan pada masa vegetative sangat berpengaruh dalam menunjang pertumbuhan. Pada umur 40 HST nilai klorofil memiliki hubungan yang kuat dengan hasil produksi. Pada fase ini nilai klorofil berpengaruh terhadap hasil produksi karena semakin banyak batang padi pada tiap-tiap rumpunnya maka akan semakin banyak malai padi. Sedangkan, yang dapat menentukan banyaknya anakan tergantung dari kesehatan dan kesuburan dari tanaman padi. Nilai klorofil dapat menentukan kesehatan dari tanaman padi pada masa pertumbuhan. Kesehatan tanaman berpengaruh terhadap banyaknya anakan batang padi yang akan dihasilkan pada tiap-tiap rumpunnya. Menurut De Datta (1981), fungsi N pada tanaman padi adalah untuk memberikan warna hijau gelap pada daun dan komponen klorofil, merangsang agar pertumbuhan cepat, serta meningkatkan ukuran tinggi tanaman, menambah jumlah anakan, ukuran daun, butiran gabah, jumlah spikelet dalam panikel, dan kandungan protein dalam biji.

Pada umur ke 60 HST nilai korelasi antara nilai klorofil dengan hasil produksi mengalami penurunan dengan nilai $r=0,835$, hal ini menunjukkan bahwa hubungan antara nilai klorofil dengan hasil produksi pada umur 60 HST memiliki nilai korelasi yang lebih rendah berdasarkan dari nilai korelasi yang dihasilkan menunjukkan bahwa hubungan antara nilai klorofil terhadap hasil produksi pada umur $60 \mathrm{HST}$ lebih rendah dibandingkan dengan pada saat tanaman padi berumur 40, dan 70 HST, penurunan nilai klorofil pada tanaman padi pada umur ke $60 \mathrm{HST}$ dikarenakan pada umur ke 60 HST tanaman padi belum dilakukan pemupukan. Pemupukan ke-2 dilakukan pada saat umur padi 63 HST jika dikaitkan antara nilai korelasi dengan pemupukan menunjukkan bahwa memang ada pengaruh nilai $\mathrm{N}$ terhadap perkembangan nilai klorofil pada tanaman padi sehingga korelasi antara nilai klorofil dengan hasil produksi pada umur $60 \mathrm{HST}$ mengalami penurunan.

Kemudian untuk mengetahui hubungan antara nilai klorofil dengan hasil produksi pada umur 70 HST dapat dilihat nilai korelasi antara nilai klorofil dengan hasil produksi pada umur 70 HST yaitu nilai $r=0,897$ berdasarkan nilai korelasi yang diperoleh antara nilai klorofil dengan hasil produksi menunjukkan bahwa pada umur 70 HST nilai klorofil memiliki pengaruh yang kuat terhadap hasil produksi. Pada umur 70 HST nilai klorofil sangat menentukan hasil produksi padi karena pada umur 70 HST malai tanaman padi sudah keluar.

Pada umur 70 HST nutrisi yang dibutuhkan harus tercukupi sesuai yang dibutuhkan oleh tanaman karena merupakan masa generative (refroduktif) tanaman padi. Fase pertumbuhan tanaman yang diduga mempunyai hubungan yang erat dengan produktivitas tanaman padi adalah tanaman pada fase awal generatif (pinnacle initiation) pada saat tanaman padi sedang produksi (Prasad, 2006).

Berdasarkan pengamatan pada setiap tahap pertumbuhan tanaman padi pada masing-masing umur tanaman yang berbeda menunjukkan bahwa korelasi pada saat tanaman padi berumur 70 HST memiliki nilai korelasi yang kuat. Hal ini membuktikan bahwa hubungan yang paling berkaitan antara nilai klorofil dengan hasil produksi dibandingkan dengan umur lainnya yaitu pada saat padi berumur 70 HST. Menurut Putri (2016) menjelaskan pada penelitiannya bahwa pada umur 70 HST nilai klorofil pada tanaman padi lebih tinggi dibandingkan dengan umur tanaman padi lainnya. Pada penelitian ini menunjukkan bahwa nilai klorofil pada tanaman yang paling tinggi dan yang paling berpengaruh terhadap hasil produksi yaitu pada umur 70 HST, maka dari itu pada umur 70 HST sangat menentukan hasil produksi pada tanaman padi untuk itu pada masa ini kecukupan nutrisi dari tanaman harus lebih diperhatikan oleh petani. 


\section{Prediksi Hasil Produksi Menggunakan Metode Regresi Linear Berganda}

Berdasarkan model regresi linear berganda dengan menggunakan empat variabel pada penelitian ini, pada masing-masing lahan diperoleh nilai Y (Persamaan 7).

$Y=-0,431513+0,045144 X 1+0,03645 X 2+$

$0,01017 \times 3+0,020551 \times 4$

Untuk mengetahui hasil produksi tanaman padi berdasarkan nilai klorofil yang diambil dengan cara non-destruktif dilapangan dapat diprediksi dengan menggunakan model rumus regresi linear berganda yang didapatkan. Rumus ini dapat dipergunakan untuk memprediksi hasil produksi pada masing-masing lahan berdasarkan nilai klorofilnya.

\section{KESIMPULAN}

Berdasarkan dari penelitian yang telah dilakukan selama satu kali musim tanam menunjukkan bahwa memang ada hubungan antara nilai klorofil dengan hasil produksi tanaman padi dan melalui model matematis yang dihasilkan dengan metode regresi linear berganda dari hasil pengukuran nilai klorofil dan hasil panen yang didapatkan dapat ditarik kesimpulan bahwa model dapat digunakan untuk memprediksi hasil produksi tanaman padi. Model prediksi hasil produksi sebagai berikut:

$Y=-0,431513+0,045144 X_{1}+0,03645 X_{2}+0,01017 X_{3}+$ $0,020551 \mathrm{X}_{4}$

Dengan mengetahui nilai klorofil tanaman padi pada masing-masing petakan tanaman padi dapat kita ketahui hasil produksi tanaman padi pada satu lahan sawah dengan metode crop cutting test yang dilakukan dalam proses pemanenan.

\section{KONFLIK KEPENTINGAN}

Penulis menyatakan tidak ada konflik atau kepentingan dengan pihak lain.

\section{DAFTAR PUSTAKA}

Cen, H., Shao, Y., Song, H., \& He, Y. (2006). Non-destructive Estimation of Rape Nitrogen Status using SPAD Chlorophyll Meter. ICSP.

Darmawan, S. (2007). Precision Farming Sebagai Sistem Pendukung Keputusan. http://ppibaraki.wordpress. com/2007/11/29/51/ [Diakses 20 Juni 2016].
De Datta, S. K. (1981). Principles and Practice of Rice Production. New York: John Willey and Sons, 618p.

Furuya, S. (1987). Growth diagnosis of rice plants by means of leaf color. Japanese Agricultural Research Quarterly, 20, 147-153.

Furuya, S. (2007). Growth diagnosis of rice plants by means of leaf colour. JARQ, 20(3), 147-153.

Gholizadeth, A., Amin, M. S. M., Anuar, A. R., \& Aimrun, W. (2009). Evaluation of SPAD chlorophyll meter in two different rice growth stages and its temporal variability. European Journal of Scientific Research, 37, 591-598.

Hayati, F. D. (2012). Pengujian Teknik Interpolasi Sediaan Tegakan dan Biomassa Berbasis IHMB pada Hutan Lahan Kering PT. Trisetia Intiga, Kabupaten Lamandau, Kalimantan Tengah. Skripsi. Bogor: Institut Pertanian Bogor.

Hussain, F., Bronson, K. F., Singh, Y., Singh, B., \& Peng, S. (2000). Use of chlorophyll metersufficiency indices for nitrogen management of irrigated rice in Asia. Agron. J., 92, 875-879.

International Rice Research institute (IRRI). (2002). Rice Almanac. Source Book for the Most Important Economic Activity on Earth. Metro Manilla, Philippines, 257 p: International Rice Research institute.

Maksum, C. (1998). Sistim Pengumpulan dan Pengolahan Data Statistik Tanaman Padi di Indonesia. Lokakarya Sistim Pemantauan dan Prediksi Padi di Indonesia. Jakarta: SARI Project - BPP Teknologi.

Pingali, P. L., Hossain, M., \& Gerpacio, R.V. (1997). Asian Rice Bowls: The Returning Crisis. Manila: International Rice Research Institute (IRRI).

Prasad, R. (2006). Fertilizer Nitrogen: Requirements and Management. In Global Aspects of Food Production M. S. Swaminathan \& S. K. Sinha (Eds.) (pp. 199-226). New Jersey-United States: Tycooly International Riverton.

Putri, R. E., Yahya, A., Adam, N. M., \& Aziz, S. A. (2016). Variability of Rice Yield With Respect To Crop Health. Jurnal Teknologi, 78(1-2), 79-85.

Santosa. (2012). Buku Ajar Metodologi Penelitian. Bogor: IPB Press.

Sastrosupadi. (2000). Rancangan Percobaan Praktis Bidang Pertanian. Edisi Revisi. Jakarta: Penerbit Kanisius.

Suryana, A. \& Mardianto, S. (2001). Bunga Rampai Ekonomi Beras. Jakarta: LPEM FEUI.

Turner, F. T. \& Jund, M. F. (1991). Chlorophyll meter to predict nitrogen topdress requirement for semidwarf rice. Agronomi Journal, 83 (5) 926-928.

Varvel, G. E., Wilhelm, W. W., Shanahan, J. F., \& Schepers, J. S. (2007). An algorithm for corn nitrogen recommendations using a chlorophyll meter based sufficiency index. Agron. J., 99: 701-706. http://doi.org/10.2134/agronj2006.0190 